\title{
Expression analysis of DNA methyltransferase and co-repressor genes in Quercus suber phellogen: an attempt to correlate with cork quality
}

\author{
Miguel Ramos ${ }^{1}$, Margarida Rocheta1, Luísa Carvalho', José Graça², Leonor Morais-Cecilio ${ }^{1 *}$ \\ From IUFRO Tree Biotechnology Conference 2011: From Genomes to Integration and Delivery \\ Arraial d'Ajuda, Bahia, Brazil. 26 June - 2 July 2011
}

\section{Background}

Cork oak (Quercus suber) is one of the most important forest species in Portugal. Cork oak produces a thick cork bark which is harvested for industrial uses. Cork quality is the most important factor that affects its uses technical performance and economic value. Cork quality is associated with many features, the most relevant being the porosity resulting from the phellogen's differentiation in filling tissue which will degenerate to lenticels. Good cork has few pores of very thin diameter being the opposite valid for low cork quality. Aiming to understand the mechanisms responsible for controlling of the molecular machinery involved in cork production, namely at the epigenetic level, it is relevant to study the expression profiles of the enzymes involved in DNA methylation in the phellogen.

Methylation of cytosines in the DNA, achieved by DNMT methyltransferases, is one of the most important factors in the regulation of gene expression [1]. In plants three DNMT classes have been identified, each one with its function: the CMT (chromomethylase) class found only in plants, is responsible for maintaining the methylation in CpHpG sequences [2]; the DRM (DomainRearranged-Methyltransferase) class is associated with de novo methylation in any context [3]; and the MET class, responsible for the maintenance of methylation in CpG zones [1]. Proteins, such as the DNA methyltransferase-associated protein (DMAP1), are known to form stable complexes with DNMTs and act as co-repressors of gene expression.

\footnotetext{
* Correspondence: Imorais@isa.utl.pt

'CBAA, ISA, Technical University Lisbon, Tapada da Ajuda, 1349-017 Lisbon, Portugal

Full list of author information is available at the end of the article
}

In this work, we report the transcriptional profile of three putative DNA methyltransferase genes from the CMT, DRM and MET classes, and one DMAP in Q. suber phellogen of trees producing good or bad quality cork.

\section{Methods}

Three Quercus suber potential producers of good quality cork and three producers of bad quality cork were selected. Samples of cork and phellogen were collected from these trees to further estimate cork quality and perform a transcriptional analysis of selected genes. Previously an in silico analysis was performed on a cork oak EST library (COEC, Cork Oak ESTs consortium). Three EST sequences, referred as DNA methyltransferases, and one as DMAP1 were selected. Each one was identified and characterized against available databases. Primers were designed to specifically amplify each sequence in real-time-PCR analysis. The actin gene was chosen as internal reference. RNA was extracted from phellogen samples, using Spectrum Plant Total RNA kit and cDNA was obtained with Retroscript kit. Gene expression was analyzed in the six phellogen samples, using qRT-PCR in triplicate reactions performed for each cDNA template with each primer pair. The NormFinder algorithm was used to evaluate the gene expression's stability using the sample 75 as reference.

\section{Results}

Measurement of cork density allowed forming two groups of trees: (1) three individuals with the lower average density $(0.289$ g.cm $-3 \pm 0.037)$ classified as good cork quality producers, (2) three trees with the highest average density $(0.388$ g.cm $-3 \pm 0.036)$ classified as bad cork quality producers. 
Homology search using BLASTP algorithm against available databases showed significant similarities between selected our putatively translated ESTs and known DNMTs (CMT3 - ABW96889, DRM2 ABW96890 and MET2 - XP_002874265) and DNMT associated proteins (DMAP1- XP_002515237) with evalues of $2 \mathrm{e}-50,5 e-95,1 e-92$, 9e-64, respectively

The expression of the three putative DNMTs and DMAP1 genes was evaluated in the phellogen of both tree groups.

The gene expression stability, evaluated through the NormFinder algorithm, showed values ranging from 0.4 for QsDRM2 to 1.5 for DMAP1. Actin also showed an appropriate value (0.7) to be used as internal control.

Bad cork quality tree \#75 was used as reference. QsMET2 and QsDMAP1 genes showed the highest expression values, while QsCMT3 and QsDRM2 presented the lowest. Comparison of both group trees revealed that, in average, the expression level of each gene is higher in the bad cork quality group than in the good cork quality (Fig1).

\section{Conclusions}

In this work we identified one functional DNA methyltransferase of each class (QsCMT3, QsDRM2 and QsMET2) and the MET1 associated protein (QsDMAP1) in cork oak phellogen. This protein has been described in humans [4] as a co-repressor of gene expression, capable of binding with other regulatory proteins such as histone deacetylases [4] which are also associated with gene silencing.

The general tendency of DNMTs to express less in trees able to produce good cork quality suggests a globally lower methylation level and therefore a lower phellogen gene repression. We can hypothesize that gene silencing is higher in bad quality producers, leading to a higher weight of genes whose expression originates defects.
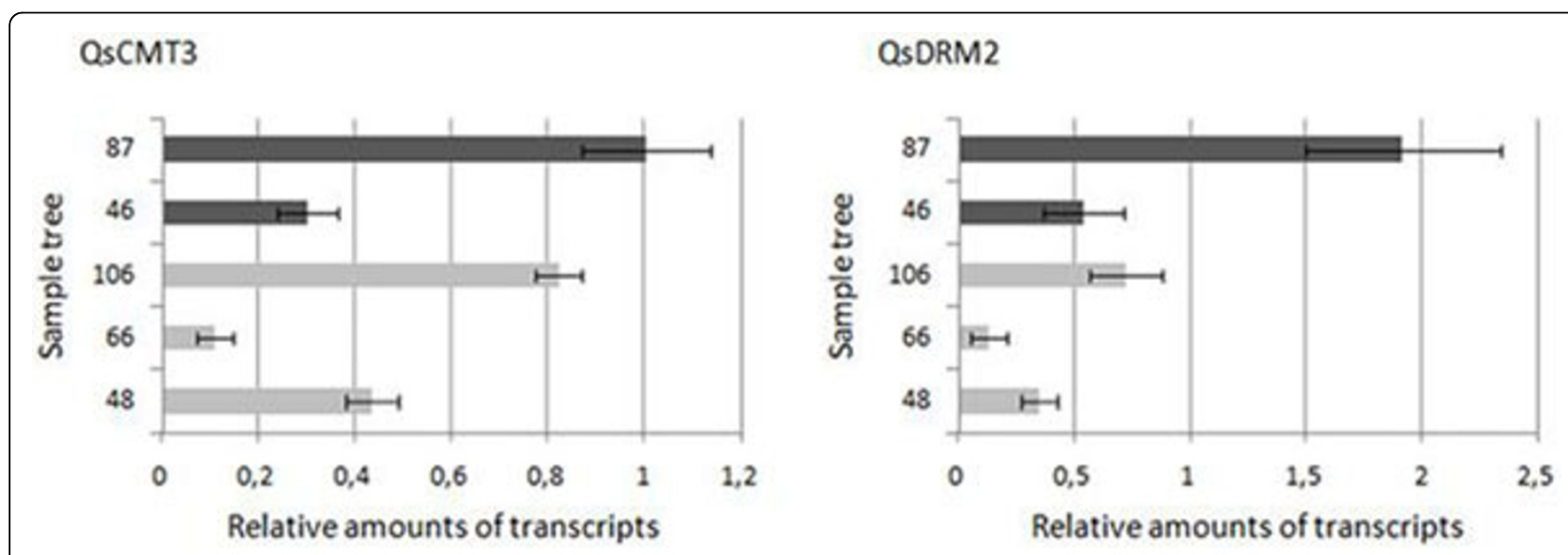

\section{QSMET2}

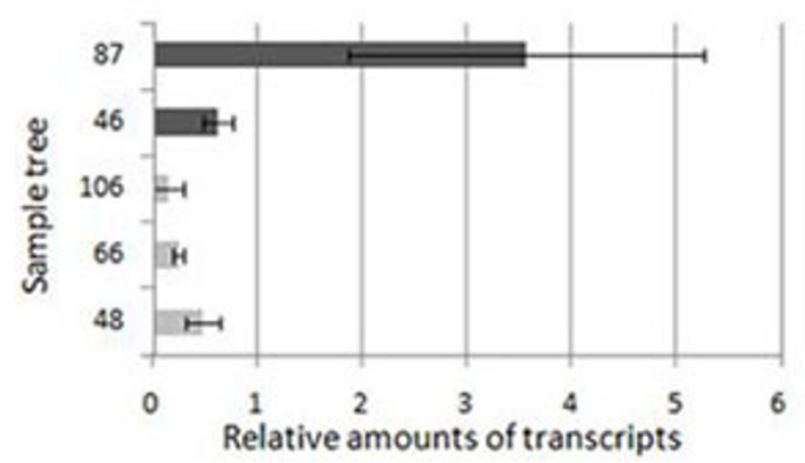

\section{QSDMAP1}

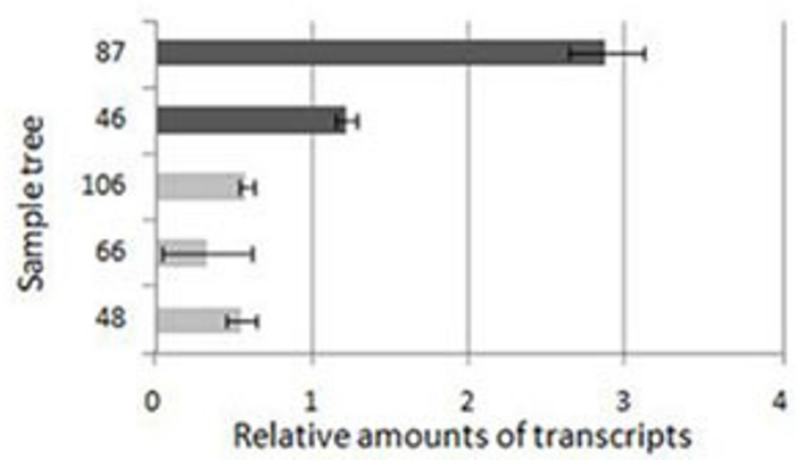

Figure 1 Comparative expression levels of each gene studied. 87 and 46 - bad cork quality producers; 106, 66 and 48, good cork quality producers. 
Gene stability analyses lead us to consider QsDRM2 as the most stable, as was already reported in other species. Therefore, this gene may be a good candidate to be used as reference gene, in future real-time-PCR analyses. This high stability seems to indicate that de novo methylation although occurring, has no influence in good or bad cork quality production. Conversely, the more variable expression, and therefore the genes that can potentially affect cork quality are QsMET2 and QsDMAP1 genes.

\section{Acknowledgments}

This work was supported by FCT Projects Sobreiro/0019/2009, PTDC/AGRCFL/104197/2008, PTDC/AGR-GPL/101785/2008

\section{Author details}

'CBAA, ISA, Technical University Lisbon, Tapada da Ajuda, 1349-017 Lisbon, Portugal. ${ }^{2}$ CEF, ISA Technical University Lisbon, Tapada da Ajuda, 1349-017

Lisbon, Portugal.

Published: 13 September 2011

\section{References}

1. Finnegan EJ, Kovac KA: Plant DNA methyltransferase. Plant Mol Biol 2000, 43:189-201.

2. Cao X, Jacobsen SE: Locus-specific control of asymmetric and CpNpG methylation by the DRM and CMT3 methyltransferase genes. PNAS 2002, 99:16491-16498.

3. Cao X, Spring NM, Muszynski MG, Phillips RL, Kaepler S, Jacobsen SE: Conserved plant genes with similarity to mammalian de novo DNA methyltransferases. PNAS 2000, 97:4979-4984.

4. Rountree MR, Bachman KE, Baylin SB: DNMT1 binds HDAC2 and a new corepressor, DMAP1, to form a complex at replication foci. Nat Genet 2000, 25:269-277.

doi:10.1186/1753-6561-5-S7-P169

Cite this article as: Ramos et al: Expression analysis of DNA

methyltransferase and co-repressor genes in Quercus suber phellogen: an attempt to correlate with cork quality. BMC Proceedings 2011 5(Suppl 7):P169.

\section{Submit your next manuscript to BioMed Central} and take full advantage of:

- Convenient online submission

- Thorough peer review

- No space constraints or color figure charges

- Immediate publication on acceptance

- Inclusion in PubMed, CAS, Scopus and Google Scholar

- Research which is freely available for redistribution

Submit your manuscript at www.biomedcentral.com/submit
C Biomed Central 